\title{
Efficient Nutrient Management for High Crop Yield and Quality in Wheat Crop in Central Uttar Pradesh, India
}

\author{
Vivek Kumar Trivedi*, Sushil Dimree, Ravendra Tomer, \\ Divankar Duby and Anubhav Trivedi
}
Department of Soil Science and Agriculture Chemistry C.S. Azad University of Agriculture and Technology, Kanpur U.P., (208002), India

*Corresponding author

\begin{tabular}{l} 
Key w o r d s \\
$\begin{array}{l}\text { Nutrient } \\
\text { management, Crop } \\
\text { yield and quality }\end{array}$ \\
\hline Article Info \\
$\begin{array}{l}\text { Accepted: } \\
\text { 07 April } 2018 \\
\text { Available Online: } \\
\text { 10 May } 2018\end{array}$ \\
\hline
\end{tabular}

\section{Introduction}

Wheat is the foremost important staple food after rice, consumed by $65 \%$ of the population in India and is likely to increase further due to changes in food habits and rise in population. Wheat is mostly consumed in the form of chapati in our country for which bread wheat is cultivated in nearly 95 per cent of the cropped area. Durum wheat, which is most suitable for making macaroni, noodles,
A field scale experiment was conducted on wheat crop in entisol of Crop Research Farm Nawabganj, C. S. Azad University of Agriculture and Technology, Kanpur during 2016-17 Indo-Gangetic alluvium of Central U.P. The treatments were Control, $100 \%$ NPK $\left(120: 60: 60 \mathrm{~kg} \mathrm{ha}^{-1}\right), 100 \% \mathrm{NPK}+\mathrm{S}_{40}, 100 \% \mathrm{NPK}+\mathrm{Zn}_{5}, 100 \% \mathrm{NPK}+\mathrm{S}_{40}+\mathrm{Zn}_{5}, 125 \% \mathrm{NPK}$, $125 \% \mathrm{NPK}+\mathrm{S}_{40}, 125 \% \mathrm{NPK}+\mathrm{Zn}_{5}, 125 \% \mathrm{NPK}+\mathrm{S}_{40}+\mathrm{Zn}_{5}$ and $150 \% \mathrm{NPK}$. There were 10 treatments and 4 replications in R.B.D. In wheat, $125 \% \mathrm{NPK}+\mathrm{S}_{40}+\mathrm{Zn}_{5}$ gave $54.88 \mathrm{q} \mathrm{ha} \mathrm{has}^{-1}$ as against the respective control of $22.69 \mathrm{q} \mathrm{ha}^{-1}$. The yield increase was significantly higher in $125 \%$ NPK over $100 \%$ NPK and $150 \%$ NPK also gave significantly higher grain yield over $125 \%$ NPK. Addition of S to $100 \%$ NPK and $125 \%$ NPK gave significantly higher yield over the NPK levels without S. In case of $100 \% \mathrm{NPK}+\mathrm{S}$ the increase in yield due to $\mathrm{S}$ application was of the order of $25 \%$. Similarly $125 \% \mathrm{NPK}+\mathrm{S}$ gave about $12 \%$ increase in yield over $125 \%$ NPK without S. Zn application to $100 \%$ NPK and $125 \%$ NPK increase the yield by $31 \%$ and $19 \%$, respectively. When $\mathrm{S}+\mathrm{Zn}$ both were applied in combination with $100 \%$ NPK and $125 \%$ NPK the magnitude of increase was $49.40 \%$ and $24.34 \%$, respectively. Wheat protein content was also increased significantly (from 11.07 to $13.64 \%$ ). The uptakes of NPK, S and $\mathrm{Zn}$ were also increased significantly due to different treatments. The treatment $125 \% \mathrm{NPK}+\mathrm{S}_{40}+\mathrm{Zn}_{5}$ gave the highest VCR 1.71 in wheat. 
was subsequently upgraded in 1978 of the status of the Project Directorate and later on was shifted to its present location at Karnal in 1990. Through coordinated research efforts, more than 316 wheat varieties suited to different agro-ecological conditions and growing situations have been released so far.

The wheat production increased from a mere 12.5 million tonnes in 1964 to around 73 million tonnes in recent years. India has the capacity to become world leader in the production of wheat. The country has already overtaken USA and attained the 76.4 million tonnes mark in 1999-2000. It is now realized that sustaining wheat productivity is essential to provide food security to the population of India, which by the year 2020 A.D. will be about 1.25 billion. The projected demand for wheat by the year 2020 A.D. will be 109 million tonnes and to achieve this new technological advances are to be made. In the area of crop improvement emphasis would be to develop new genotypes that are responsive to high input management and capable of yielding beyond $7.0 \mathrm{t} / \mathrm{ha}$. The wheat growing area in the country is classified into six major zones. Based on the state wise acreage currently wheat is being grown on an area of over 27 million hectares. About $72 \%$ of the area falls in two mega zones comprising of north western plain zone and north eastern plain zone followed by $17 \%$ in $\mathrm{CZ}$ while NHZ, PZ and SHZ constitutes about $11 \%$ area. Out of the total wheat area, $82-85 \%$ falls under irrigated conditions while the rest is under rainfed agriculture. In the current wheat production level of 73 million tonnes, north western plain zone alone produces about $56 \%$ followed by north eastern plain zone (less than half of north western plain zone) and Central zone. It is estimated that wheat production can be increased beyond 95 million tonnes if these gaps are bridged. North eastern plains zone and central zone are capable of contributing significantly in future although north western plains continue to dominate in wheat production and are likely to increase further due to changes in food habits.

Wheat (Triticum aestivum L. em Thell.) is the first important and strategic cereal crop for the majority of world's population. It is the most important staple food of about two billion people (36\% of the world population). Worldwide, Wheat provides nearly $55 \%$ of the carbohydrates and $20 \%$ of the food calories consumed globally (Breiman and Graur, 1995). It exceeds in acreage and production every other grain crops (including rice, maize, etc.) and is therefore, the most important cereal grain crop of the world.

Wheat is an edible grain, one of the oldest and most important of all the cereal crops. Though grown under a wide range of climates and soils, wheat is best adapted to temperate regions with rainfall between 30 and $90 \mathrm{~cm}$. Winter and spring wheat's are the major two types of the crop, with the severity of the winter determining whether a winter or spring type is cultivated. The world's main wheat producing regions are China, India, United States, Russian Federation, France, Australia, Germany, Ukraine, Canada, Turkey, Pakistan, Argentina, Kazakhstan and United Kingdom (FAO, 2003). Common wheat or bread wheat (T. aestivum) - one of the hexaploid species that is most widely cultivated in the world. Spelt ( $T$. spelta) - other hexaploid species cultivated in limited quantities. Spelt is sometimes considered as a subspecies of the closely related species common wheat (T. aestivum), and its botanical name is considered to be $T$. aestivum ssp. spelta. Tetraploid species. Durum (T. durum) - The only tetraploid form of wheat widely used today, and the second widely cultivated wheat. Khorasan (T. turgidum ssp. turanicum, also called $T$. turanicum) is a tetraploid wheat species. It is an ancient grain type; It refers to a historical region in modern-day Afghanistan 
and the northeast of Iran. This grain is twice the size of modern-day wheat and is known for its rich nutty flavour. Diploid species. Einkorn (T. monococcum) - A diploid species with wild and cultivated variants. Domesticated at the same time as emmer wheat, but never had the same importance. Although most wheat is grown for human food and about only 10 percent is retained for seed and industry (for production of starch, paste, malt, dextrose, gluten).

\section{Materials and Methods}

To carry out present investigation, a field experiment was conducted at Nawabganj Research Farm, Chandra Shekhar Azad University of Agriculture and Technology, Kanpur, during rabi season of 2016-17. The experiment was laid out in different fields to avoid the residual effects. Cultural operations adopted before sowing of maize and wheat, were similar during the year of experimentation. The farm is situated in the vicinity of Kanpur city to the east side about $1.2 \mathrm{Km}$ from the main campus on G.T. Road in the Indo gangetic plain of central Uttar Pradesh. The district Kanpur is situated in subtropical and semi-arid zone falling between the parallels $25^{\circ} 26^{\prime}$ to $26^{\circ} 58^{\prime}$ north latitude and $79^{\circ} 31^{\prime}$ to $80^{\circ} 34^{\prime}$ east longitude, and is located at an elevated belt of Gangetic plains of Central Uttar Pradesh.

Soil samples were collected with the help of steel augar, air-dried and ground with pestle and mortar to pass through $2 \mathrm{~mm}$ sieve. The soil of experimental field is normal in EC and $\mathrm{pH}$ and low in organic carbon, available N2 and available $\mathrm{Zn}$ but medium in case of available $\mathrm{P}, \mathrm{K}$ and available $\mathrm{S}$. The soil reaction $(\mathrm{pH})$ and electrical conductivity (EC) were determined in saturation extract as per as procedure described by Jackson (1973). The soil organic carbon (OC) was estimated by wet digestion method of Walkley and Black
(1934) and available $\mathrm{N}$ of the soil was determined by Subbaiah and Asija (1956). The available phosphorus in the soil was extracted by employing Olsen extractant $(0.5 \quad M$ $\mathrm{NaHCO}_{3}$ ) as described by Olsen et al., (1954) and the available $\mathrm{K}$ in the soil was extracted by using neutral ammonium acetate and the content was determined by aspirating the extract into flame photometer (Jackson 1973). The available sulphur (S) in the soils was extracted with $0.15 \% \mathrm{CaCl}_{2} .2 \mathrm{H}_{2} \mathrm{O}$ solution as described by Williams and Steinbergs (1959) and the content of DTPA extractable micronutrients viz., zinc $(\mathrm{Zn})$ in soil was estimated using 1:2 soil to extractants ratio (Lindsay and Norvell 1978). The plant samples were taken simultaneously and washed with tape water followed by washing with $0.1 N \mathrm{HCL}$ and de-ionized water. The samples were air-dried and kept in oven at 60 to $70{ }^{\circ} \mathrm{C}$ for drying till the constant weight. The samples were ground in a steel Willey mill and digested with 4:1 di-acid mixture of $\mathrm{HNO}_{3}$ and $\mathrm{HCLO}_{4}$ (Jackson 1973). The plant samples were also analysed for N P K, S and Zn. Nitrogen was determined by Kjeldal's method and phosphorus was determined calorimetrically. Potassium was determined by flame photometric method. Sulphur was determined by turbidimetric method (Chaudhary and Cornfield 1966) using spectrophotometer, while zinc content was determined by atomic absorption spectrophotometer (AAS).

\section{Results and Discussion}

\section{Grain yield}

There were significant variations in the data under different treatments. It varied from (22.69 to $54.88 \mathrm{q} \mathrm{ha}^{-1}$ ) with a mean value of $44.31 \mathrm{q} \mathrm{ha}^{-1}$. Among NPK levels $125 \%$ NPK gave significantly higher yield to $100 \%$ NPK to the tune of about $40 \%$ in grain yield. Among NPK levels $150 \%$ NPK gave 
significantly higher yield over $125 \%$ NPK to the tune of about $21 \%$ in grain yield. Addition of sulphur to $100 \%$ NPK also caused significant increase of about $24 \%$. At $125 \%$ NPK addition of $\mathrm{S}$ resulted in significant increase of about 9\%. Addition of zinc to $100 \%$ NPK also caused significant increase of about $30 \%$. At $125 \%$ NPK, addition of $\mathrm{Zn}$ gave significant increase of about $19 \%$. Addition of S+Zn to $100 \%$ NPK also caused significant increase of about $48 \%$. At $125 \%$ NPK addition of $\mathrm{S}+\mathrm{Zn}$ resulted in significant increase of about $21 \%$. Results of this study are in agreement with those of following workers Shukla and Shrama (1994) and Kumar and Ahalawat (2006) (Table 1).

\section{Straw yield}

There were significant variations in the data under different treatments. During first year it varied from 28.99 to $73.14 \mathrm{q} \mathrm{ha}^{-1}$ with a mean value of $56.41 \mathrm{q} \mathrm{ha}^{-1}$. Among NPK levels $125 \%$ NPK gave significantly higher yield over to $100 \%$ NPK to the tune of about $43 \%$ in straw yield. Further increase in NPK doses to $150 \%$ the increase in yield was significant. Addition of sulphur to $100 \%$ NPK caused significant increase of about $30 \%$ in grain yield. However, there were small but significant increases in straw yield due to individual addition of S to $125 \%$ NPK.

Addition of zinc to $100 \%$ NPK also caused significant increase of about $34 \%$. At $125 \%$ NPK addition of $\mathrm{Zn}$ also caused significant increase in the straw yield. Addition of $\mathrm{S}+\mathrm{Zn}$ to $100 \%$ NPK also caused significant increase of about $52 \%$. At $125 \%$ NPK addition of $\mathrm{S}+\mathrm{Zn}$ resulted significant increase of about $27 \%$. Results in this study are in agreement with those of following worker Soffi et al., (2004), Onasanya et al., (2009) and Barsoum (1995). Thus it was indicated that addition of $\mathrm{S}, \mathrm{Zn}$ and $\mathrm{S}+\mathrm{Zn}$ to NPK caused positive effect on the increase in grain and straw yield to a significant extent and the results justificaly proned the balancing effect of nutrients.

\section{Nutrient content and uptake}

The concentration and uptake of $\mathrm{N}, \mathrm{P}, \mathrm{K}, \mathrm{S}$ and $\mathrm{Zn}$ were estimated in grain and straw after the harvest of the crop. It was revealed that the concentration of nutrients and the biomass per $s e$ increased with the increasing doses of NPK from control to $150 \%$ NPK. Furthermore, at each level of NPK the concentrations of NPK $\mathrm{S}$ and $\mathrm{Zn}$ were increased at the significant level. This was the region that uptake (nutrient concentration $\times$ biomass yield) increased significantly (Table 2-5).

\section{Nitrogen}

Nitrogen content varied from 1.97 to $2.18 \%$ in grain and from 0.42 to $0.53 \%$ in straw. The highest values were obtained in treatment $125 \% \mathrm{NPK}+\mathrm{S}_{40}+\mathrm{Zn}_{5}$ and this increase was $42 \%$ higher in case of grain and 29\% higher in case of straw over control. Mean nitrogen uptake varied from (44.69 to 119.63 ) $\mathrm{kg} \mathrm{ha}^{-1}$ in grain and from (11.88 to 39.49) $\mathrm{kg} \mathrm{ha}^{-1}$ in straw. The highest values were obtained in treatment $125 \% \quad \mathrm{NPK}+\mathrm{S}_{40}+\mathrm{Zn}_{5}$ and this increase was $175 \%$ higher in case of grain and $200.25 \%$ higher in case of straw over control, indicating that the nitrogen absorption increased appreciably under different treatments. Similar results were given by Singh and Brar (2006) and Stevenson et al., (2005).

\section{Phosphorus}

Mean phosphorus content varied from 0.30 to $0.34 \%$ in grain and from 0.11 to $0.18 \%$ in straw on the basis of mean of two years. The highest values were obtained in treatment $125 \% \mathrm{NPK}+\mathrm{S}_{40}+\mathrm{Zn}_{5}$ \& this increase was $14 \%$ higher in case of grain and 63\% higher in case of straw over control. 
Table.1 Yield \% increased over control

\begin{tabular}{|c|c|c|c|c|}
\hline Treatments combination & Grain yield in $\mathbf{q ~ h a}^{-1}$ & $\begin{array}{c}\text { \% Increase over } \\
\text { control }\end{array}$ & Grain yield in $\mathrm{q} \mathrm{ha}^{-1}$ & $\begin{array}{c}\text { \% Increase over } \\
\text { control }\end{array}$ \\
\hline Control & 22.69 & & 28.99 & \\
\hline $100 \%$ NPK & 32.36 & 29.88 & 39.94 & 27.41 \\
\hline $100 \% \mathrm{NPK}+\mathrm{S}_{40}$ & 40.42 & 43.86 & 51.42 & 43.62 \\
\hline $100 \% \mathrm{NPK}+\mathrm{Zn}_{5}$ & 42.05 & 46.04 & 53.71 & 46.02 \\
\hline $100 \% \mathrm{NPK}+\mathrm{S}_{40}+\mathrm{Zn}_{5}$ & 47.97 & 52.69 & 60.80 & 53.31 \\
\hline $125 \%$ NPK & 45.28 & 49.88 & 57.38 & 49.47 \\
\hline $125 \% \mathrm{NPK}+\mathrm{S}_{40}$ & 49.24 & 53.92 & 62.34 & 53.49 \\
\hline $125 \% \mathrm{NPK}+\mathrm{Zn}_{5}$ & 54.16 & 58.10 & 68.43 & 57.63 \\
\hline $125 \% \mathrm{NPK}+\mathrm{S}_{40}+\mathrm{Zn}_{5}$ & 54.88 & 58.65 & 73.14 & 60.36 \\
\hline $150 \%$ NPK & 54.14 & 58.09 & 67.98 & 57.35 \\
\hline S.E. (d) & 0.489 & & 0.661 & \\
\hline C.D. $(P=0.05)$ & 1.005 & & 1.356 & \\
\hline
\end{tabular}

Table.2 Effect of different treatments on content of N, P, K, S and Zn

\begin{tabular}{|c|c|c|c|c|c|c|c|c|c|c|}
\hline \multirow{2}{*}{ Treatment } & \multicolumn{3}{|c|}{$\mathbf{N}(\%)$} & \multicolumn{3}{c|}{$\mathbf{P}(\%)$} & \multicolumn{3}{c|}{ K $(\%)$} & \multicolumn{3}{c|}{ Zn $(\mathbf{\% p m})$} \\
\hline & Grain & Straw & Grain & Straw & Grain & Straw & Grain & Straw & Grain & Straw \\
\hline T1 & 1.97 & 0.41 & 0.30 & 0.11 & 0.21 & 1.74 & 0.12 & 0.12 & 19.10 & 24.39 \\
\hline T2 & 2.02 & 0.45 & 0.31 & 0.12 & 0.23 & 1.93 & 0.17 & 0.13 & 21.61 & 26.73 \\
\hline T3 & 2.08 & 0.48 & 0.32 & 0.13 & 0.24 & 1.95 & 0.18 & 0.13 & 24.39 & 29.31 \\
\hline T4 & 2.05 & 0.47 & 0.31 & 0.13 & 0.25 & 1.97 & 0.19 & 0.13 & 26.71 & 32.31 \\
\hline T5 & 2.09 & 0.51 & 0.33 & 0.15 & 0.28 & 2.07 & 0.22 & 0.16 & 31.17 & 34.23 \\
\hline T6 & 2.07 & 0.47 & 0.31 & 0.13 & 0.24 & 1.94 & 0.18 & 0.14 & 26.31 & 31.20 \\
\hline T7 & 2.12 & 0.50 & 0.32 & 0.14 & 0.25 & 1.97 & 0.19 & 0.14 & 29.70 & 34.13 \\
\hline T8 & 2.14 & 0.49 & 0.31 & 0.14 & 0.27 & 1.99 & 0.21 & 0.15 & 32.89 & 36.22 \\
\hline T9 & 2.18 & 0.54 & 0.34 & 0.18 & 0.31 & 2.19 & 0.24 & 0.18 & 34.43 & 36.71 \\
\hline T10 & 2.10 & 0.50 & 0.32 & 0.14 & 0.25 & 1.95 & 0.17 & 0.14 & 30.64 & 32.70 \\
\hline SE \pm & $\mathbf{0 . 0 1 5}$ & $\mathbf{0 . 0 0 8}$ & $\mathbf{0 . 0 0 5}$ & $\mathbf{0 . 0 0 5}$ & $\mathbf{0 . 0 0 6}$ & $\mathbf{0 . 0 0 5}$ & $\mathbf{0 . 0 0 6}$ & $\mathbf{0 . 0 0 3}$ & $\mathbf{0 . 8 5 4}$ & $\mathbf{0 . 8 6 3}$ \\
\hline C.D. (P=0.05) & $\mathbf{0 . 0 3 0}$ & $\mathbf{0 . 0 1 8}$ & $\mathbf{0 . 0 1 1}$ & $\mathbf{0 . 0 1 1}$ & $\mathbf{0 . 0 1 3}$ & $\mathbf{0 . 0 1 0}$ & $\mathbf{0 . 0 1 2}$ & $\mathbf{0 . 0 0 8}$ & $\mathbf{1 . 7 5 2}$ & $\mathbf{1 . 7 7 2}$ \\
\hline
\end{tabular}

Table.3 Effect of different treatments on uptake of N, P, K, S and Zn

\begin{tabular}{|c|c|c|c|c|c|c|c|c|c|c|}
\hline \multirow[t]{2}{*}{ Treatment } & \multicolumn{2}{|c|}{$\mathbf{N}\left(\mathrm{kg} \mathrm{ha}^{-1}\right)$} & \multicolumn{2}{|c|}{$\mathbf{P}\left(\mathrm{kg} \mathrm{ha}^{-1}\right)$} & \multicolumn{2}{|c|}{$\mathrm{K}\left(\mathrm{kg} \mathrm{ha}^{-1}\right)$} & \multicolumn{2}{|c|}{$\mathrm{S}\left(\mathrm{kg} \mathrm{ha}^{-1}\right)$} & \multicolumn{2}{|c|}{$\mathrm{Zn}\left(\mathrm{g} 100 \mathrm{~kg}^{-1}\right)$} \\
\hline & Grain & Straw & Grain & Straw & Grain & Straw & Grain & Straw & Grain & Straw \\
\hline $\mathrm{T} 1$ & 44.69 & 11.88 & 6.80 & 3.18 & 4.76 & 50.44 & 2.72 & 3.47 & 433.37 & 707.06 \\
\hline $\mathrm{T2}$ & 65.36 & 17.97 & 10.03 & 4.79 & 7.44 & 77.08 & 5.50 & 5.19 & 699.29 & 1067.59 \\
\hline $\mathrm{T3}$ & 84.07 & 24.68 & 12.93 & 6.68 & 9.70 & 100.26 & 7.27 & 6.68 & 985.84 & 1507.12 \\
\hline $\mathrm{T4}$ & 86.20 & 25.24 & 13.03 & 6.98 & 10.51 & 105.80 & 7.98 & 6.98 & 1123.15 & 1735.37 \\
\hline $\mathrm{T5}$ & 100.25 & 31.00 & 15.83 & 9.12 & 13.43 & 125.85 & 10.07 & 9.72 & 1495.22 & 2081.18 \\
\hline T6 & 93.72 & 26.96 & 14.03 & 7.45 & 10.86 & 111.31 & 8.15 & 8.03 & 1191.31 & 1790.25 \\
\hline $\mathrm{T7}$ & 104.38 & 31.17 & 15.75 & 8.72 & 12.31 & 122.80 & 9.35 & 8.72 & 1462.42 & 2127.66 \\
\hline $\mathrm{T} 8$ & 115.90 & 33.53 & 16.78 & 9.58 & 14.62 & 136.17 & 11.37 & 10.76 & 1781.32 & 2478.53 \\
\hline T9 & 119.63 & 39.49 & 18.65 & 13.16 & 17.01 & 160.17 & 13.17 & 13.16 & 1889.51 & 2684.96 \\
\hline T10 & 113.69 & 33.99 & 17.32 & 9.51 & 13.53 & 132.56 & 9.20 & 9.51 & 1658.84 & 2222.94 \\
\hline $\mathrm{SE} \pm$ & 1.317 & 0.480 & 0.432 & 0.341 & 0.724 & 1.221 & 0.485 & 0.278 & 0.633 & 0.815 \\
\hline C.D. $(P=0.05)$ & 2.703 & 0.985 & 0.886 & 0.700 & 1.487 & 2.505 & 0.996 & 0.571 & 1.838 & 1.672 \\
\hline
\end{tabular}


Table.4 Effect of different fertilizer treatments on protein and lysine in wheat

\begin{tabular}{|c|c|c|c|c|}
\hline \multirow{2}{*}{$\begin{array}{l}\text { Treatments } \\
\text { combination }\end{array}$} & \multicolumn{2}{|c|}{ Protein Lysine } & \multicolumn{2}{|c|}{ Lysine } \\
\hline & $(\%)$ & yield $\mathrm{kg} \mathrm{ha}^{-1}$ & $(\%)$ & yield $\mathrm{kg} \mathrm{ha}^{-1}$ \\
\hline Control & 11.07 & 251.17 & 0.55 & 12.47 \\
\hline $100 \%$ NPK & 12.05 & 389.93 & 0.52 & 16.82 \\
\hline $100 \% \mathrm{NPK}+\mathrm{S}_{40}$ & 12.44 & 502.42 & 0.51 & 20.61 \\
\hline $100 \% \mathrm{NPK}+\mathrm{Zn}_{5}$ & 12.42 & 522.26 & 0.45 & 18.92 \\
\hline $100 \% \mathrm{NPK}+\mathrm{S}_{40}+\mathrm{Zn}_{\mathbf{5}}$ & 13.20 & 633.20 & 0.43 & 20.62 \\
\hline $125 \%$ NPK & 12.61 & 570.98 & 0.41 & 18.56 \\
\hline $125 \% \mathrm{NPK}+\mathrm{S}_{40}$ & 13.08 & 644.05 & 0.37 & 18.21 \\
\hline $125 \% \mathrm{NPK}+\mathrm{Zn}_{5}$ & 12.88 & 697.58 & 0.37 & 20.03 \\
\hline $125 \% \mathrm{NPK}+\mathrm{S}_{40}+\mathrm{Zn}_{5}$ & 13.64 & 748.56 & 0.34 & 18.65 \\
\hline $150 \%$ NPK & 12.88 & 697.32 & 0.34 & 18.40 \\
\hline S.E. (d) & 0.241 & & & \\
\hline C.D. $(P=0.05)$ & 0.494 & & & \\
\hline
\end{tabular}

Table.5 Economic impact evaluation of different treatments in wheat crop

\begin{tabular}{|l|}
\hline Treatments combination \\
\hline Control \\
\hline $100 \% \mathrm{NPK}$ \\
\hline $100 \% \mathrm{NPK}+\mathbf{S}_{40}$ \\
\hline $100 \% \mathrm{NPK}+\mathbf{Z n}_{5}$ \\
\hline $100 \% \mathrm{NPK}+\mathbf{S}_{40}+\mathbf{Z n}_{5}$ \\
\hline $125 \% \mathrm{NPK}$ \\
\hline $125 \% \mathrm{NPK}+\mathbf{S}_{40}$ \\
\hline $125 \% \mathrm{NPK}+\mathbf{Z n}_{5}$ \\
\hline $125 \% \mathrm{NPK}+\mathbf{S}_{40}+\mathbf{Z n}_{5}$ \\
\hline $150 \% \mathrm{NPK}$ \\
\hline
\end{tabular}

Mean phosphorus uptake varied from 6.80 to $18.65 \mathrm{~kg} \mathrm{ha}^{-1}$ in grain and from 3.18 to 13.16 $\mathrm{kg} \mathrm{ha}^{-1}$ in straw.

The highest values were obtained in treatment $125 \% \mathrm{NPK}+\mathrm{S}_{40}+\mathrm{Zn}_{5}$ and this increase was $179 \%$ higher in case of grain and $313 \%$ higher in case of straw over control, indicating that the phosphorus absorption was increased appreciably under different treatments. Similar results were followed by Sunar and Galantini (2012) and Rashid M. and M. Iqbal (2012).

\section{Value cost ratio $(\mathrm{N}: \mathrm{C})$ of Wheat}

\begin{tabular}{|l|}
\hline NIL \\
\hline 0.29 \\
\hline 0.58 \\
\hline 0.71 \\
\hline 1.30 \\
\hline 1.12 \\
\hline 1.36 \\
\hline 1.53 \\
\hline 1.71 \\
\hline 1.53
\end{tabular}

\section{Potassium}

Unlike other nutrients the concentration of Potassium was maximum in the maize crop. Potassium content varied from $0.21 \%$ to $0.31 \%$ the corresponding value in straw 1.74 (minimum) to $2.19 \%$ (maximum values) were given by control and $125 \% \mathrm{NPK}+\mathrm{S}_{40}+\mathrm{Zn}_{5}$, respectively. The percentage increase in best treatment over control was $48 \%$ in grain and $27 \%$ in straw. The mean potassium uptake ranges from (4.76 to 17.01$) \mathrm{kg} \mathrm{ha}^{-1}$ and $(50.00$ to 159.60$) \mathrm{kg} \mathrm{ha}^{-1}$ in grain and straw, 
respectively. The corresponding magnitude of percentage increase in treatment $125 \%$ $\mathrm{NPK}+\mathrm{S}_{40}+\mathrm{Zn}_{5}$ over control were about 274 and 220, in grain and straw respectively. The high magnitude of increase might be attributed to the increase in large concentration of potassium and simultaneous increase in plant biomass under balanced fertilizer treatments. Similar result were followed by Rashid and Iqbal (2012) and Rajdhar and Singh (1990).

\section{Sulphur}

The average sulphur content varied from $0.12 \%$ in control to $0.24 \%$ in $125 \%$ $\mathrm{NPK}+\mathrm{S}_{40}+\mathrm{Zn}_{5}$ and $0.12 \%$ to $0.18 \%$ in grain and straw, respectively. The increases in sulphur content under different treatment were significant. Similarly the average uptake of sulphur varied from (2.62 to 12.92) and (3.46 to 13.15$) \mathrm{kg} \mathrm{ha}^{-1}$ in grain and straw respectively. In both the cases the minimum and maximum value were obtained in control and $125 \% \mathrm{NPK}+\mathrm{S}_{40}+\mathrm{Zn}_{5}$. The magnitude of increase in sulphur uptake in best treatment was about 4.93 times and 3.8 times greater over control. Again this increase might be ascribed to the increase in concentration of sulphur and biomass under balanced nutrition. Similar results were followed by Tiwari (1997).

\section{Zinc}

The average Zinc content varied from (18.69 to 33.76 ) and (24.55 to 36.52 ) ppm in grain and straw, respectively. The lowest and highest concentrations were obtained in control and $125 \% \mathrm{NPK}+\mathrm{S}_{40}+\mathrm{Zn}_{5}$, respectively. The variation trends are in zinc content due to different treatment were similar to dose described for sulphur. Similar results were followed by Nandram (1996) and Singh and Triphati (2008). The results were significant with Uptake of zinc the range of variation on mean bases was (433.37 to 1889.51) and

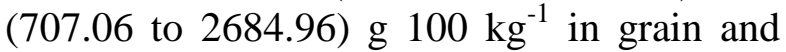
straw, respectively. The zinc uptake in straw was roughly 1.40 times as compared to grain. It appeared that the treatments under balance nutrition were responsible for significant increases in zinc concentration and plant biomass.

\section{Quality of wheat}

In this study an attempt has been made to see the possibility of improvement in wheat quality through balanced nutrition. Protein is the major consideration in wheat derived foods, marketing and exports of wheat. In several countries the market price of wheat is determined on the basis of its true protein content in grain. It is notable that in many parts of the world nitrogen is applied in much higher doses without maintaining balance with other major and micronutrients. The practice gives higher grain yield but it quality is deteriorated due to accumulation of soluble nitrogen in higher proportion. The real answer to this problem is to balance the high dose of nitrogen with other nutrient like $\mathrm{P}, \mathrm{K}, \mathrm{S}$ and $\mathrm{Zn}$ in particular. Therefore the present study was conducted by applying $100 \%$ NPK, $125 \%$ NPK and $150 \%$ NPK and former two levels were combined with $\mathrm{S}, \mathrm{Zn}$ and $\mathrm{S}+\mathrm{Zn}$. The results obtained are discussed below.

\section{Protein}

Protein varied from 11.07 in control to 13.64 $\%$ in $125 \% \quad \mathrm{NPK}+\mathrm{S}_{40}+\mathrm{Zn}_{5}$ and latter considered the best treatment. The protein varied significantly under different treatments. Addition of $\mathrm{S}$ and $\mathrm{Zn}$ also increased the protein content significantly. The increase in protein content due to addition of sulphur may be ascribed to the reason that the sulphur is a component of protein. To obtain quantitative evaluation of protein yield was computed from the data on 
yield and protein content of grain. Protein yield varried from 251.17 (control) to 748.56 $\mathrm{kg} \mathrm{ha}^{-1}\left(125 \% \mathrm{NPK}+\mathrm{S}_{40}+\mathrm{Zn}_{5}\right)$. It meant that the nutrient application resulted in 3 time increase in protein harvest. Results of this study are in agreement with those of fallowing workers: Karasu (2012), Stewart and Porter et al., (1969), Das and Datta (1973).

\section{Lysine}

The lysine content was analysed in triplicate on composite sample. It varied from $0.53 \%$ to $0.37 \%$ and all the fertilizers treatment had depressing effect on lysine content. In other words the highest value was recorded in control. The lysine availability was worked out as a function of protein yield and lysine content was expressed as $\mathrm{kg} \mathrm{ha}^{-1}$. The lowest $\left(12.47 \mathrm{~kg} \mathrm{ha}^{-1}\right)$ and the highest $\left(20.62 \mathrm{~kg} \mathrm{ha}^{-1}\right)$ values were found in control and $125 \%$ $\mathrm{NPK}+\mathrm{S}_{40}+\mathrm{Zn}_{5}$. Thus it was observed that the lysine harvest was mainly governed by the yield of protein and not its concentration. Similar results have been reported by Majumdar et al., (2012).

\section{Economic impact evaluation of different treatment in wheat}

VCR value is the reliable parameter for assessment of value cost ratio. Which may be explained as the net profit obtained for investment of one rupee. In the best treatment $125 \% \mathrm{NPK}+\mathrm{S}_{40}+\mathrm{Zn}_{5}$ was 1.71 in wheat, which means investment of one rupee gave net profit of rupees one 171 in wheat making allowance for yield due to the native soil nutrients. The cost of the input and those of yield were calculated on the prevailing rates at the time of harvest. Finally, it was evident that the yield of wheat crop wheat grain $54.88 \mathrm{q} \mathrm{ha}^{-1}$ and in straw $73.14 \mathrm{q} \mathrm{ha}^{-1}$ was also utilized by $150 \mathrm{~kg} \mathrm{~N}, 90 \mathrm{~kg} \mathrm{P}, 90 \mathrm{~kg} \mathrm{~K}, 40 \mathrm{~kg} \mathrm{~S}$ and $5 \mathrm{~kg}$ $\mathrm{Zn}$.
In the condition obtained during the experimentation in the respect of soil varieties and other factors inter alia application of $125 \% \mathrm{NPK}+\mathrm{S}_{40}+\mathrm{Zn}_{5}$ gave the best results in the respect of growth parameters, yield, nutrient uptake, protein, lysine content in wheat. The highest yield was observed 54.88 $\mathrm{q} \mathrm{ha}^{-1}$ in wheat. Followed by $100 \% \mathrm{NPK}+\mathrm{S}+$ $\mathrm{Zn}$ (with $47.97 \mathrm{q} \mathrm{ha}^{-1}$ ). The former treatment was adoptive for yield maximization and the latter treatment is useful for the farmers endowed with lesser investment.

\section{References}

A.O.A.C (1970). Official method of analysis. Association of official Analytical chemists, Washington. DC., USA: 174.

Ali, M.M, Main, M.S, Islam, A, Begum, J.A and Fevdaus, A.K.M. (2004). Interaction effect of sulphur and phosphorus on wheat. Asian Journal of Plant Science3 (5): 597-601.

Anand, N. and Patil, B.N. (2005). Effect of micronutrients on growth and yield of wheat. Karnataka Journal of Agricultural Science 18 (3): 604-608.

Azad, A.S. (1993). Response of wheat to graded doses of NPK in soil testing low, medium and high in respect to $\mathrm{P}$ and $\mathrm{K}$ in Gurudaspur district of Punjab. Journal of Pot culture Research, 9 (3): 266-270.

Barbara, Ceh, Hrastar Robert, Tajnsek, Anton andKosir Joze Izt. (2008) Impact of source and application time of sulphur on the yield, oil content and protein content in winter oilseed rape. Acta agriculturae Slovenica, 91- 1.

Brar, Benipal, B.S. and Singh, J.S.D. (2009). Response of wheat to different levels of phosphorus and sulphur in alluvial soils of Punjab. Indian Journal of Ecology36 (1): 18-21.

Chandel, S.R.S. (1990). A handbook of Agricultural Statistics. Achhal 
Prakashan Mandir, Pandu Nagar, Kanpur Nagar 843-853.

Chapman, H.D. and Pratt, P.F. (1961). Method of analysis for soils, plants and water. University of California, U.S.A.

Dhaliwal, S. S., Sidhu, S. S., Walia, S. S. and Gurpreet Singh (2011). Effect of different cropping systems on distribution of DTPA-extractable and total $\mathrm{Zn}, \mathrm{Cu}, \mathrm{Fe}$ and $\mathrm{Mn}$ fraction in alluvial soils of Punjab. Environment and Ecology. 29 (1): 293-300.

Dokie, d. and Kostic, M. (1991). Effect of nitrogen nutrition on wheat yield in a long term experiment. Arhiv-zapoljoprivredne Muke, 52 (188): 283297.

Gupta, A.P., Antil, R.S., Narwal, R.P. and Roop Singh (1996). Utilization of applied phosphorus by wheat as influenced by ash application. Annals of Biology (Ludhiana) 12(1): 19-24.

Palora, K.B., Sardhana, R.V., Parmar, K.B., Babariya, N.B. and Patel, K.G. (2010). Given $\mathrm{K}$ uptake to produce grain and straw yield significantly. Asian Journal of Soil Science. 4 (2): 228-235.

Singh, N.B, Kumar, Vinay, Singh, G.S, Singh, Y.P, Singh, I.J, Kumar, J, Singh, K.N. and Shrivastava J.K. (2009). Variability in response to Zinc application in wheat genotypes. Indian Journal of Plant Physiology 14 (4): 413-417.

Weisler, F. Behrens, T. and Horst W.J. (2001). The role of nitrogen efficient cultivars in sustainable agriculture. Sciences World Journal1 (S2): 61-69.

\section{How to cite this article:}

Vivek Kumar Trivedi, Sushil Dimree, Ravendra Tomer, Divankar Duby and Anubhav Trivedi. 2018. Efficient Nutrient Management for High Crop Yield and Quality in Wheat Crop in Central Uttar Pradesh, India. Int.J.Curr.Microbiol.App.Sci. 7(05): 812-820. doi: https://doi.org/10.20546/ijcmas.2018.705.099 